\title{
X. Descriptions of some new Species of exotic Coleopterous
} Insects. By J. O. Westwood, F.L.S., \&c.

[Read 5 June, 1837.]

\section{Section Heteromera.}

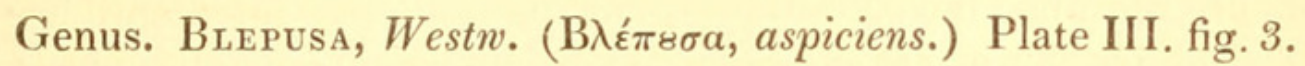
Genus singulare. Cistelides cum Conopalpo, \&c. conjungere videtur.

Corpus oblongum, postice attenuatum, rigidum.

Caput (fig. 3a) mediocre, postice in collum contractum. Oculi maximi, capitis partem majorem occupantes, supra fere connexi, et anticè convergentes. Labrum (fig. 3 b) transversoquadratum, angulis anticis rotundatis, et in medio subemarginato; margine subsetoso. Maxilla (fig. $3 \mathrm{c}$ ) lobis duobus, externo majori quasi articulato, apice rotundato piloso, interno tenui apice setoso. Palpi maxillares 4 -articulati, articulis $1 \mathrm{mo}$ et 3 tio brevibus, 2 do longiori ad apicem paullo crassiori, 4to maximo transverso securiformi. Mentum (fig. $3 d$ ) parvum urniforme, angulis lateralibus acutis. Labium menti fere magnitudine, lateribus rotundatis et ciliatis. Palpi labiales breves 3-articulati, articulo ultimo magno securiformi. Antenna graciles filiformes, sub latera producta capitis, prope oculos, insertæ; articulo 1 mo brevi, 2do minutissimo, 3tio reliquis parum longiori.

Thorax transversus, capite fere duplo latior, lateribus irregulariter rotundatis, margine postico in medio rotundato producto, dorso subdepresso. Scutellum parvum. Elytra oblonga, postice attenuata, basi thorace paullo latiora, costata. Pedes robusti, femoribus crassis, tibiæ longiores, tarsi 4 antici 5 -articulati, articulis intermediis subtus membranaceo-productis, integris. Ungues basi subtus dilatati, dentibus 4 vel 5 armati (fig. $3 e$ ).

This singular genus serves to connect in a very interesting manner some of the tribes of which Latreille has composed his division of the Heteromerous Coleoptera named Stenelytra. It agrees with some of the Cistelide in the serrated structure of the ungues, whilst the singular form of the palpi serves to show a much nearer relation with Conopalpus, Nothus, $\& c$. It appears nearly allied to Allecula, and especially to Lobopoda of Solier. (Ann. Soc. Ent. d. France, 1835, p. 233.)

VOL. III. 
Sp. 1. Blepusa costata, Westw.

Nigra, nitida, thoracis margine postico punctato, elytris striatopunctatis et costatis, tarsis piceis.

Long. corp. lin. 6.

Habitat in Mexico? D. Cuming.

In Mus. Dom. Norris, M. E. S.

Caput nigrum, læve, nitidum, oculis pallidis lutescentibus; palpis, labro et antennarum articulorum apicibus piceis. Thorax lævis, nitidus, subconvexus, lineâ impressâ longitudinali, lateribus margineque postico tenue marginatis, hoc foveis duobus intra angulos posticos margineque ipso punctato. Pedes nigri, tibiarum apicibus tarsisque piceis. Elytra nigra, nitida, in singulo striæ 9 punctorum impressorum, costisque elevatis tribus (sc. inter strias 2 et 3,4 et 5 et 6 et 7 , e suturâ); striâ alterâ abbreviatâ versus scutellum.

This interesting insect is from the rich collection of T. Norris, Esq., of Redvales, Lancashire, to whom I am indebted for an opportunity of examining and describing it. He obtained it from Mr. Cuming, but is not aware of its precise locality. It is, however, most probably from Mexico, or some adjacent part of South America, from which other allied species described by M. Solier have been received.

Section Tetramera, Latreille.

Sub-Section Longicornes, Latreille.

Genus. Rhipidocerus, Westw. ('Pıтis, flabellum, et кєраs, cornu.) Plate III. fig. 2.

Genus singulare, inter genera Phønicocerum et Polyozam,* quasi intermedium.

Corpus oblongum, depressum.

Caput (fig. $2 a$, e latere, $2 b$, subtus visum) thorace minus, facie depressâ. Mandibulæ (fig. $2 d, 2 e$ ) parvæ, corneæ, subtriangulares, interdum dente minuto ante medium armatæ, denteque altero laterali. Labrum (fig. $2 c$ ) parvum, transverso-triangulare, ciliatum. Maxillæ (fig. $2 f$ ) parvæ, membranaceæ; lobo interno fere obliterato, lobo externo elongato, curvato, ad apicem longe setoso. Palpi maxillares brevissimi, 4 -articulati, articulis 1 et 3, 2 et 4 æqualibus. Mentum (fig. $2 g$ ) parvum, transversum, antice angustatum, truncatum. Labium

* Phanicocerus Dejeanii, Latr.=Psygmatocerus Wagleri, Perty; but the insect figured in Griffith's Animal Kingdom, under the former name, is the Polyoza Lacordairei, Serville. 
membranaceum, emarginatum, ciliatum. Palpi labiales brevissimi, 3-articulati, articulo basali minuto. Antennæ in utroque sexu corporis longitudine, 11-articulatæ, articulo basali reliquis crassiori, 2ndo minuto, 8 proximis in mare, postice longè flabellatis, striatis, ultimo longo, flabellum terminante; in fœmina vero simplicibus, 8 vo, 9 no, et $10 \mathrm{mo}$, antice paullo productis, (fig. $2 h$, caput et pronotum $q$.)

Thorax transversus spinâ laterali utrinque armatus. Elytra subdepressa, sericeo-punctata, apicibus integris. Pedes mediocres, simplices.

This genus is not only interesting on account of the beautiful structure of the antennæ of the males, of which the genera Psygmatocerus and Phcenicocerus, alone* in the vast tribes of the Linnæan Cerambyces, offer any analogous instance, but also from the geographical situation which it occupies, being an inhabitant of New Holland, whereas the two genera above mentioned are from Brazil. In the structure of the mouth it approaches nearest to Anacolus. In some respects, however, it seems allied to Lamia, whilst the peculiar appearance of the very minutely punctured elytra most nearly resemble some of the Cerambyces and Stenocori.

\section{Sp. 1. Rhipidocerus Australasia, Westw.}

Obscurè viridis punctatissimus, luteo-subsericeus, antennis masculinis brunneis, fœmininis fulvis apicibus articulorum nigris, pedibus brunneo-fulvis, femorum apicibus obscurioribus. Long. corp. to lin. 8; q lin. 15.

Habitat. in Australasiâ.

In Mus. Soc. Linn., Lond., et P. Walker, Eq. [nunc Hope.]

* Mr. Newman has recently described another longicorn genus with flabellate antennæ, also from New Holland, under the name of Petalodes laminosus.Entomologist, p. 9. Still more recently (June, 1842) I have seen in the collection of M. Reich, at Paris, another flabellated species from New Holland, which may be thus concisely characterized :-

\section{Piesarthrius? Hope, Proc. Zool. Soc. 1840, p. 55.}

P. Reichii, Westw. P. capite et pronoto obscure fuscis, varioloso-punctatis et fulvo-pilosis; elytris piceo-rufis, maculâ magnâ discoidali communi ante medium, antice bifidâ, strigisque duabus posticis luteis ; pronoto subquadrato ; antennis flabellatis, articulis longitudine crescentibus; elytris apice rotundatis et ad sutura breviter aculeatis.

Long. corp. lin. 10.

Habitat Sydney, Nov. Ho!l.

Mus. D. Reich, Parisiis. 


\section{$2 \mathrm{BHL}$ Biodiversity Heritage Library}

Westwood, J. O. 1842. "X. Descriptions of some new Species of exotic Coleopterous Insects." Transactions of the Entomological Society of London 3, 69-71. https://doi.org/10.1111/j.1365-2311.1842.tb03254.x.

View This Item Online: https://www.biodiversitylibrary.org/item/48701

DOI: https://doi.org/10.1111/j.1365-2311.1842.tb03254.x

Permalink: https://www.biodiversitylibrary.org/partpdf/37517

\section{Holding Institution}

Smithsonian Libraries

\section{Sponsored by}

Smithsonian

\section{Copyright \& Reuse}

Copyright Status: Public domain. The BHL considers that this work is no longer under copyright protection.

This document was created from content at the Biodiversity Heritage Library, the world's largest open access digital library for biodiversity literature and archives. Visit BHL at https://www.biodiversitylibrary.org. 